\section{IGNORÂNCIA MORAL E O PAPEL DAS VIRTUDES}

\author{
MORAL IGNORANCE AND THE ROLE OF VIRTUES
}

\author{
DENIS COITINHO ${ }^{1}$ \\ (UNISINOS/Brasil)
}

\begin{abstract}
RESUMO
O objetivo deste artigo é investigar o problema da ignorância moral, especificamente, quero saber em que medida uma ação errada cometida por um agente responsável pode ser apropriadamente censurada, considerando que a ação errada foi cometida por ignorância. Inicio com uma descrição do fenômeno da ignorância moral e uma definição. Posteriormente, investigo como a virtude epistêmica da autonomia e a virtude moral da justiça nos auxiliam a melhor lidar com o problema em questão a partir do escopo da responsabilidade coletiva. Por fim, ressalto os aspectos sociais deste tipo de ignorância, com destaque para os fenômenos do viés cognitivo e progresso moral. Proponho que a ignorância moral de um agente pode ser um alvo apropriado de censura apenas quando ele estiver justificado epistemicamente de forma moderada, mas não expressar as virtudes cidadãs da autonomia e justiça.
\end{abstract}

Palavras-chave: Ignorância moral; Censura; Autonomia; Justiça; Responsabilidade coletiva; Viés cognitivo.

\begin{abstract}
The aim of this article is to investigate the problem of moral ignorance, specifically, I want to know to what extent a wrong action committed by a responsible agent can be properly blamed, considering that the wrong action was committed from ignorance. I will start with a description of the phenomenon of moral ignorance and a definition. Later, I will investigate how the epistemic virtue of autonomy and the moral virtue of justice help us to better deal with the problem in question from the scope of collective responsibility. Finally, I will highlight the social aspects of this type of ignorance, with emphasis on the phenomena of cognitive bias and moral progress. I will propose that an agent's moral ignorance can be an appropriate target of blame only when he is epistemically justified in a moderate way, but does not express the citizen virtues of autonomy and justice.
\end{abstract}

Keywords: Moral ignorance; Blame, Autonomy, Justice, Collective responsibility, Cognitive bias.

Em que medida os atos errados, dos quais um agente é responsável, cometidos por ignorância de certos fatos ou certas normas podem ser desculpados pelos agentes de uma dada comunidade moral e política ou em que medida esta ignorância deve ser apropriadamente censurada? Vejamos dois casos para ilustrar melhor o problema. Em primeiro de julho de 2019, o Japão voltou a caçar comercialmente baleias depois de trinta anos de proibição, o que gerou uma forte crítica dos ambientalistas do mundo todo. $\mathrm{O}$ país asiático já havia se retirado de programas de proteção e avisou em dezembro de 2018 que voltaria à caça comercial no ano seguinte, o que acabou ocorrendo. Acontece que essa medida provocou repúdio global e temores a respeito do destino desses animais. A crítica da comunidade global tomou por base que é errado matar baleias seja porque baleias estejam em extinção, seja para manter a biodiversidade dos mares, sendo, inclusive, a proteção às baleias um grande símbolo da luta ambientalista no mundo 
todo. ${ }^{2}$ Uma vez que os japoneses alegam que o consumo de carne de baleia garante a saúde da população, pode-se estipular que eles ignoram o fato de que "matar baleias é errado". A questão que surge é se essa ignorância pode ser desculpada ou se ela pode ser legitimamente censurada?

Outro caso relevante é o da escravidão. O Brasil, por exemplo, teve a instituição da escravidão tomada como legal durante três séculos, do séc. XVI até o XIX, escravizando 4,9 milhões de pessoas nesse período. Os escravos, vindos sobretudo de Angola, eram submetidos a longas jornadas de trabalho sem remuneração, torturas, castigos físicos variados, e ausência de qualquer tipo de direito. Mesmo com essa situação injusta, a escravidão era considerada como correta pela ampla maioria da população brasileira e mundial, seja se considerarmos os produtores rurais, os políticos, os religiosos e até mesmo a elite africana que vendia os escravos para os portugueses. Assim, pode-se estipular que a instituição da escravidão teve por base a ignorância do fato de que "a escravidão é errada". A questão relevante, então, é a de saber se este tipo de ignorância pode ser desculpada ou se ela pode ser censurada de forma apropriada. ${ }^{3}$ Em outras palavras, a questão será investigar se seria adequado ou não culpar os que escravizaram com base na censura por sua ignorância do fato de que "a escravidão é errada".

Vejam que meu ponto será refletir em que medida a censura a um certo ato errado cometido por um agente responsável é legítima, como, por exemplo, caçar baleias ou escravizar seres humanos, quando o agente em questão sabe o que está fazendo, isto é, está no controle da ação, mas não sabe que tal coisa é errada, como não saber que "matar baleias é errado" ou que "a escravidão é injusta". Em outras palavras, relacionarei o fenômeno da ignorância moral com a questão da responsabilidade do agente, responsabilidade tomada, aqui, como censurabilidade, de forma que um agente será moralmente responsável por uma ação se a mesma for censurável e se ele responder por ela, sobretudo, por gerar ressentimento ou indignação, e se ele for culpado do ato. Com essa restrição, o agente só poderá ser responsabilizado moralmente pelo ato se ele puder ser censurado por sua ignorância. O problema é que tradicionalmente a ética tem por foco a responsabilidade dos agentes sobre suas ações, intenções, omissões e até sobre as consequências danosas dos atos, não dando uma atenção especial aos casos de ignorância, ignorância que é anterior aos atos realizados. Imaginem alguém que usa uma certa marca de roupa, mas que ignora que a empresa que a fabrica faz uso de trabalho escravo infantil. O agente em tela poderia ser claramente censurado por usar esta roupa, mas poderia ele ser censurado por sua ignorância, uma vez que não teve a intenção de defender a escravidão? Em outros termos, ele deveria ter conhecimento do fato de que a tal empresa se utiliza de trabalho escravo infantil e, por essa razão, deixar de usar tal marca? Ele estava obrigado a saber melhor sobre o caso? ${ }^{4}$

De forma geral, se alguém age por ignorância, ele pode ser facilmente desculpado do ato, como se poderia, por exemplo, facilmente desculpar Édipo do incesto, uma vez que o mesmo ignorava que Jocasta era sua mãe. Embora ele estivesse no controle da ação de se casar com Jocasta, agindo livremente 
e não deterministicamente/coercitivamente, ele desconhecia o fato de quem era sua mãe verdadeira e, assim, ele não poderia ser apropriadamente responsabilizado pelo incesto, dado que ele não poderia ser apropriadamente censurado por sua ignorância. Por mais que a condição epistêmica de ter conhecimento dos fatos relevantes que cercam a ação seja uma condição necessária para a responsabilização moral em casos regulares, além da condição de controle, é claro, vou considerar casos de ignorância em que o agente poderia ser censurado apropriadamente, evitando dois opostos: tomar a ignorância como sempre censurável ou, alternativamente, como sempre desculpável. ${ }^{5}$ No que segue, irei esclarecer, inicialmente, o fenômeno da ignorância moral e, posteriormente, refletir sobre a responsabilidade moral dos agentes a partir das virtudes epistêmicas e morais de autonomia e justiça para, por fim, investigar sobre o escopo da responsabilidade coletiva. A estratégia de fazer uso da linguagem das virtudes para lidar com o problema da ignorância moral é que ela parece se contrapor a uma visão individualista e não contextualista da agência moral, visão que é bastante usual nas teorias tradicionais, o que implica considerar as capacidades tanto cognitiva como motivacional dos agentes de uma forma solipsista e não de uma maneira associacional. Minha intenção será a de chamar atenção para os aspectos sociais da ignorância moral, em especial, destacando os fenômenos de viés cognitivo e de progresso moral.

\section{II}

Para tentar compreender em maior detalhe o fenômeno da ignorância moral e procurar estipular uma definição é importante esclarecer, inicialmente, o que estou entendendo por ignorância. Ignorância é tomada geralmente como ausência de conhecimento e, dado que o conhecimento é tradicionalmente visto como crença verdadeira justificada, a ignorância em questão estaria ligada ao assegurar crenças morais falsas. Por exemplo, ignorar que "a escravidão é errada" por ferir os direitos inalienáveis de vida, liberdade e igualdade das pessoas seria o mesmo que ter uma crença moral falsa como fundamento da ação de escravizar. Considerando, a partir dos exemplos de Gettier, que se pode ter crenças verdadeiras justificadas e mesmo assim não se ter conhecimento, como a crença de Smith de que "O homem que conseguirá o emprego tem dez moedas no bolso", tomarei o conhecimento como similar a ter uma crença apta ou bem-sucedida ou como expressão de certas virtudes, tomando como referência a epistemologia das virtudes. Assim, a ignorância seria uma condição ou estado em que um agente usaria crenças malsucedidas como fundamento de suas decisões e ações, podendo ser tomada, também, como um estado de ausência de certas virtudes. ${ }^{6}$ Não sendo o conhecimento equivalente a uma crença verdadeira justificada, a ignorância não será interpretada simplesmente como ausência de conhecimento (proposicional), podendo tanto significar o uso de crenças malsucedidas, quanto a suspensão de juízo ou ausência de consideração sobre um tema, ou até uma situação de incerteza. ${ }^{7}$ 
Outra observação inicial importante é que a ignorância de certos fatos ou normas no campo moral se relaciona com a condição epistêmica e não com a condição metafísica da responsabilidade moral. A intuição básica é a de que um agente é responsável moralmente apenas se ele conhece os fatos particulares que envolvem sua ação e age a partir de um tipo apropriado de crenças e intuições. Por exemplo, para alguém ser responsabilizado por parricídio seria necessário que o agente soubesse que aquela pessoa que ele matou é seu pai. Não tendo o conhecimento específico deste fato e nem tendo a intenção própria de matar o pai, o ato em tela só poderia ser classificado como assassinato, mas não como parricídio. O problema da ignorância, assim, não teria uma relação direta com a condição metafísica da responsabilidade, que é a de tomar o agente responsável apenas se ele puder agir livremente, sem determinação/coerção, tendo o controle da ação na forma de poder escolher entre as possibilidades alternativas. Por exemplo, podendo escolher entre assassinar ou não assassinar, escolha essa que não seria determinada ou que não estaria envolvida pela coerção. ${ }^{8}$

A partir dessas observações iniciais, deixem-me, agora, tentar identificar os diversos elementos que parecem constituir o fenômeno da ignorância moral. Parto de uma distinção importante entre ignorância de certos fatos e ignorância de certas normas. Por exemplo, o agente que caça e/ou come baleias pode agir a partir de sua ignorância de que as baleias estão em extinção ou de que as baleias são necessárias para garantir a biodiversidade dos mares. Mas, pode ser o caso, também, do agente ignorar que os animais não-humanos têm direitos ou que não devemos ser cruéis com os animais ou, ainda, que as espécies em extinção devem ser protegidas, bem como a biodiversidade. No primeiro caso, temos a ignorância sobre certos fatos, tal como o fato não moral das baleias estarem em extinção ou das baleias garantirem a biodiversidade. No segundo caso, temos a ignorância de certas normas, como a norma moral dos animais terem direitos ou da norma de não sermos cruéis com os animais não-humanos ou, ainda, da norma moral que exige a proteção das espécies em extinção e da biodiversidade. ${ }^{9}$

Essa distinção se mostra relevante uma vez que a ignorância direcionada aos fatos não morais parece ser sempre menos censurável do que a ignorância das normas morais propriamente ditas. Por exemplo, ignorar, no século XVIII, que os africanos ou negros são pessoas, parece ser menos censurável (ou mais desculpável) do que ignorar que as pessoas têm direitos inalienáveis, tais como vida, integridade, liberdade etc. e, por isso, elas não devem ser escravizadas. Talvez isso possa ser explicado pelas diferenças existentes entre os diversos tipos de ignorância, tais como a ignorância factual, a ignorância moral e a ignorância legal, por exemplo. A ignorância factual é sempre desculpável, enquanto a ignorância moral é muitas vezes censurável. Vejamos um caso ilustrativo disso. Se um agente não sabe a fórmula de báscara ou desconhece os conceitos básicos da genética provavelmente ele não será censurado pelos membros da comunidade moral-política em que vive. Diferentemente de um agente que é ignorante a respeito dos direitos humanos de vida, liberdade e igualdade, como no caso de um terrorista 
do Estado Islâmico. Esse tipo de desconhecimento provavelmente será fortemente censurado pelos agentes da comunidade, nesse caso global, em razão deles serem os critérios normativos básicos para a convivência social, isto é, por garantirem a estabilidade social. Nesse sentido, é interesse notar que a ignorância legal é sempre censurável, sendo passível de censura legal (punição), pois todo o cidadão é obrigado a conhecer as leis, bem como não ser negligente ou imprudente etc. Por exemplo, se há uma lei que proíbe a caça de certos animais, tal como o javali, e um caçador caça esse animal ignorando a lei, essa ignorância não the servirá de desculpas e, se for provada sua culpa do ato, ele será punido da mesma maneira que será punido o caçador que tem o conhecimento da lei em tela. No âmbito do direito penal, a ignorância da norma não serve como desculpa aceitável, enquanto que do ponto de vista moral, a ignorância é muitas vezes desculpável, como poderia ser moralmente desculpável a ação de caçar javali sem ter o conhecimento da proibição legal que foi estabelecida, considerando que o ato era habitual no passado. Mas, porque teríamos essa diferença?

Talvez a chave para entender esta distinção seja entender um pouco melhor o que estaria envolvido nos diversos domínios da realidade social, tais como a ciência, a moral e o direito. O âmbito científico, por exemplo, sendo hegemonicamente descritivo, não parece suscitar ressentimento nos agentes da comunidade quando um certo indivíduo falha ao tentar explicar a realidade através de crenças verdadeiras, e isto porque essa falha não parece envolver nada como uma má intenção ou maldade deliberada. Isso talvez explique a razão da ignorância factual ser sempre desculpável. É diferente no caso moral, em que a falha em identificar as crenças bem-sucedidas, que aqui podem ser tomadas como razões morais, pode estar relacionada com um certo descaso do agente por suas obrigações comuns, podendo gerar emoções negativas, tais como ressentimento ou indignação na comunidade, o que provavelmente nos remeta à qualidade da intenção ou motivação (vontade) do agente. Essa poderia ser a razão da ignorância moral ser muitas vezes desculpável, mas, em alguns casos, ser apropriadamente censurável. Por sua vez, no âmbito do direito, mais especificamente o penal, a falha do agente em agir de acordo com as leis (normas) geralmente traz consequências negativas para todos na comunidade política, como, por exemplo, o dano individual ou mesmo a perda de um certo bem que se quer proteger, como uma espécie em extinção. Aqui não está em questão, ao menos inicialmente, a qualidade da intenção do agente, não se tratando de uma resposta emocional ao ato ilegal, mas da consideração das consequências negativas do ato. Isso possivelmente explique porque a ignorância legal é sempre censurável em algum nível. ${ }^{10}$

Veja que essa diferença entre os tipos de ignorância nos remete claramente a uma distinção relevante na forma de se compreender a censura, especialmente no que toca aos âmbitos do direito e da moral. Na esfera moral, a reponsabilidade do agente está ligada à censurabilidade de certas ações e mesmo intenções em razão dessas ações e intenções gerarem atitudes reativas, ou seja, gerarem emoções de ressentimento e indignação na comunidade por um certo ato errado cometido ou gerarem uma 
reprovação do caráter do agente. A censura, assim, poderia ser vista como uma atitude reativa por certas ações ou intenções que não parecem demostrar a preocupação relevante com o bem dos outros. É diferente do domínio jurídico, em que a reponsabilidade do agente parece mais ligada às obrigações, isto é, aos direitos e deveres que os cidadãos estabelecem em uma dada comunidade política. Aqui a censura não seria uma atitude reativa, não estando primariamente ligada ao sentimento de ressentimento e indignação, mas teria um caráter claramente comunicativo, de forma que censurar alguém, que é o mesmo que puni-lo, implicaria em comunicar ao agente que ele agiu erradamente (ilegalmente) em razão de não respeitar os direitos alheios. Como se pode notar, a autoridade normativa no direito é claramente intersubjetiva, isto é, em segunda pessoa, sendo o cumprimento das normas uma exigência social, enquanto na moral ela é, na grande parte dos casos, subjetiva, quer dizer, em primeira pessoa, pois a exigência de um comportamento virtuoso ou correto viria do próprio agente, como no caso dele exigir de si mesmo um comportamento corajoso, moderado, solidário, ou que maximiza o bem-estar ou que se deseja que seja universalizado. ${ }^{11}$

A partir desta distinção realizada, creio que a especificidade da ignorância no âmbito moral seja mais facilmente identificada. Uma questão particular é que o reconhecimento desta ignorância deveria interromper o ressentimento ou indignação sentida pela comunidade em razão de um certo ato errado cometido por um agente culpado. Sendo esses sentimentos reativos a base da censura, o reconhecimento da ignorância de certos fatos ou normas deveria ocasionar a desculpa do erro ou a retirada da censura, desde que se pudesse perceber o remorso no agente que errou e foi ignorante, sobretudo a partir de um pedido de perdão. Lembremos o caso do Rei Ticar, Gah Ibrahim, que pede perdão a um brasileiro que é membro de sua etnia, como reportado na nota dois, pelo comportamento dos ancestrais em escravizar seu próprio povo porque o fizeram por ignorância, ignorância sobre o erro da escravidão e sobre a igualdade e liberdade das pessoas como direitos inalienáveis. Note-se que esse pedido por reconciliação teve por base o sentimento de remorso pela ignorância passada de um certo fato cometido por um certo agente, aqui um agente coletivo que pode ser compreendido como povo, podendo ser tomado como uma razão suficiente para a desculpa, isto é, para a interrupção da censura, como de fato ocorreu no caso em tela. Nessa dimensão, a ignorância moral seria apropriadamente desculpável. Não seria o caso de alguém que alega ignorância, mas não demonstra remorso e/ou não pede perdão. Nesse caso, penso que o agente teria uma forte razão para continuar a censura. Censura, agora, não apenas do ato, mas, também, do estado ou condição do agente ou, mais especificamente, do seu caráter ou motivação. ${ }^{12}$

Uma última questão sobre a ignorância moral antes de tentarmos formular uma definição do fenômeno, a saber, o problema do regresso. Se alguém age por ignorância, o agente ou é desculpado ou é censurado por tal ignorância. Se alguém é censurado por tal ignorância, parece que a censura em questão estaria ligada à violação de uma obrigação anterior, que seria a de se informar adequadamente, de forma 
a não ser ignorante. Mas, veja que violar a obrigação de informação só seria possível ou por acrasia ou ignorância. Sendo por acrasia, isto é, por fraqueza da vontade, o agente saberia que é certo se informar adequadamente, mas sua ação não seguiria esse conhecimento por razões motivacionais. Sendo por ignorância, o agente não saberia de sua obrigação de se informar. O problema é que isso parece nos remeter a um regresso, significando que o agente seria quase sempre desculpado e quase nunca censurado (PEELS, 2017, p. 3).

De posse dessas características anteriormente elencadas, deixem-me formular uma definição de ignorância moral (IM), ao menos provisoriamente:

IM: Fenômeno que ocorre quando um agente $S$ comete um ato errado $A$ do qual é responsável, sendo um alvo apropriado de censura $C$, sendo que $S$ está no controle da ação, isto é, sabe o que está fazendo, mas não sabe que tal coisa é errada, desconhecendo certos fatos ou normas que envolvem $A$, o que pode anular a censura $C$ atribuída a $S$ por $A$.

A partir dessa definição, a estratégia será analisar duas virtudes, uma epistêmica e outra moral, virtudes que parecem relevantes para anular ou ao menos atenuar a culpa atribuída ao agente em casos de ignorância moral, de forma que se o agente expressar essas virtudes ele não poderá ser apropriadamente censurado. Por óbvio, os agentes que não demonstrarem possuir esse conjunto de virtudes poderão ser adequadamente responsabilizados, o que implicará ser um alvo correto de censura. O foco recairá nas virtudes da autonomia e da justiça, observando os aspectos sociais das práticas tanto cognitivas como morais e, destacando, também, as circunstâncias formativas envolvidas no fenômeno em questão. Inicio com a virtude da autonomia, que tanto pode ser vista como uma virtude intelectual como pode ser interpretada como uma virtude moral.

\section{III}

Roberts e Wood, em seu livro Intellectual Virtues, analisam corretamente a virtude da autonomia como uma virtude intelectual e que possui aspectos sociais significativos, de maneira a não interpretá-la como uma virtude individualística ou solipsista. Para eles, a autonomia é uma conquista cultural que passa de geração a geração, sendo exemplificada pela figura do estudante ou pesquisador, que, por um lado, possuem a capacidade de trabalhar independentemente, mas, por outro, manifestam uma dependência inteligente em relação aos professores e mesmo colegas. Autonomia, assim, envolve uma disposição e habilidade de utilizar a inteligência e conhecimento dos outros quando necessária e, também, de manter suas convicções mesmo sob ameaça, podendo ser vista como uma forma específica de adaptação (ROBERTS \& WOOD, 2007, p. 257-258).

Como já identificado corretamente por Kant, a autonomia é a capacidade do agente usar o seu próprio entendimento sem direção de outra pessoa, isto é, sem ser tutelado. É uma capacidade de pensar 
por si mesmo, o que implica em ter a coragem para usar sua própria razão sem ser direcionado pelos outros, tanto para explicar o mundo como para decidir o que deve ser feito. Dessa forma, autonomia pode ser vista como uma habilidade apropriada de pensar por si mesmo e não ser dependente ou influenciado pelas outras pessoas. Como a etimologia revela claramente, a palavra "autonomia" vem das palavras gregas “autós", que significa "mesmo", “ele mesmo" e a palavra “nómos" que significa "lei” ou "regra". Assim, esta virtude pode ser definida como autorregulação, ou seja, como a capacidade do agente ser a regra ou a lei para si mesmo, sendo contrária à heteronomia, isto é, como uma ação regulada pelas outras pessoas, como uma regulação externa ao agente, que seria o mesmo que heterorregulação. Aqui autonomia pode ser entendida em contraposição à heteronomia. ${ }^{13}$

$\mathrm{Na}$ interpretação de Roberts e Wood, autonomia intelectual é tomada como a virtude da autorregulação, mas que mantém características sociais. Em suas palavras:

\footnotetext{
Assim, autonomia intelectual é a virtude da autorregulação apropriada, mas sempre com o olhar da regulação do outro ou a possibilidade disto. (Autonomia é, acima de tudo, uma virtude social.) Se tentamos imaginar os extremos da autorregulacão e da regulação pelos outros, o absurdo de ambas situações se manifesta. A virtude nessa área da vida deve participar tanto da autorregulação como da regulação dos outros, e a tarefa do epistemólogo da virtude é delimitar estas interações no traço de caráter do agente (ROBERTS \& WOOD, 2007, p. 259).
}

Veja que com essa interessante forma de interpretar essa virtude intelectual, a autonomia não pode ser confundida com uma ação solipsista, não sendo um agente autônomo o mesmo que um autodidata, e isso porque o conhecimento tem fortes traços sociais, sendo uma atividade coletiva. Também, o agente autônomo não pode ser confundido com a pessoa que apenas repete um certo conteúdo aprendido de algum experto. Esta virtude pressupõe uma dose adequada de curiosidade e independência, por um lado, mas, também, exige uma porção correta de humildade e respeito para aprender com os outros. Dessa maneira, a autonomia pode ser vista como uma mediedade entre um extremo da independência absoluta e outro extremo da dependência completa. Como considerada na tradição da ética das virtudes, a autonomia é um meio termo justo ente a autorregulacão absoluta e a heterorregulação total. ${ }^{14}$

Como o conhecimento é social, isto é, é uma atividade coletiva, uma vez que é uma atividade de seguir regras e toda atividade de seguir regras é coletiva, a virtude da autonomia pode ser tomada como uma disposição para compreender que a vida epistêmica é regulada pelos outros, bem como é uma disposição para orientar as próprias práticas epistêmicas com o reconhecimento do fato dessa dependência. Assim, as pessoas seriam menos autônomas se refutassem este reconhecimento da heterorregulação, tendo por consequência a falha do que seria o melhor epistemicamente. Importante ressaltar que todo o conhecimento que temos é mediado pelo outros, desde sua aquisição, bem como sua manutenção, sendo que uma parte significativa do conhecimento humano é essencialmente herdado. 
Penso que o progresso moral é um exemplo ilustrativo disso, observando mais especificamente o conhecimento moral. Vejamos por que. ${ }^{15}$

O fenômeno do progresso moral pode ser caracterizado como a expansão do círculo moral ao longo da história da humanidade ou como uma maior inclusividade de agentes na avaliação moral, o que parece nos apontar que o conhecimento ético é coletivo antes que individual. A partir de um enfoque naturalista-evolucionista, podemos entender a moral como uma relação de cuidado entre os agentes para evitar o dano e uma exigência por reciprocidade. No passado (pré-história), apenas os membros de um pequeno círculo tinham a proteção moral ao cuidado e à reciprocidade, especialmente os membros do sexo masculino. Com o passar do tempo, os outros povos foram incluídos nessa preocupação, bem como as mulheres, os membros de outras etnias, como os negros e, mais recentemente, até mesmo os animais não-humanos e a natureza em geral foram incluídos na preocupação ética, como podemos perceber pela ampla aceitação da declaração universal dos direitos humanos na atualidade. Tendo em mente essas características do progresso moral, então, pode-se estipular que o reconhecimento da injustiça da escravidão no séc. XIX e do erro do sexismo no século XX, por exemplo, bem como o reconhecimento dos direitos dos animais no final do século XX e início do século XXI, ao menos ao nível de se considerar como errados os atos cruéis cometidos contra os animais, não foi resultado de uma modificação individual no julgamento ético, mas uma atividade coletiva que consistiu na correção das distorções do raciocínio moral, que excluíam arbitrariamente certos entes da preocupação normativa. Assim, não seria a autonomia individual tomada isoladamente o que teria possibilitado essa mudança dos juízos morais ao longo de nossa história. Ao contrário, o ato autônomo parece depender dessa dimensão coletiva, o que pode significar que a responsabilidade pela ignorância em relação a esses temas morais não poderia ser atribuída exclusivamente aos indivíduos, mas, antes, a todo um grupo. ${ }^{16}$

Com isso em mente, é importante destacar, também, que assim como as outras virtudes, a autonomia é uma modificação da vontade do agente que se dá através do exercício, isto é, do hábito adquirido. Dessa forma, as pessoas se tornariam autônomas pelo processo educativo, uma vez que aumentam seu conhecimento em um certo campo, podendo agir sem tanta orientação de uma autoridade externa, tal como a de um professor, tornando-se elas próprias expertos. Mas, mesmo assim, a virtude da autonomia irá requerer humildade para contar com auxílio em várias situações, seja de consulta, orientação ou mesmo da revisão de certo conhecimento. Autonomia, então, é em parte uma expertise e em parte é um traço de caráter. É um tipo de sabedoria sobre o conhecimento, um autoentendimento amplamente perspectivo com respeito às áreas de aprendizagem, inclusive, reconhecendo os limites desse conhecimento. Note-se que a virtude da autonomia parece intrinsicamente ligada à virtude intelectual da sabedoria prática ou prudência, que é a disposição para reconhecer os meios necessários para se alcançar certo fim e uma capacidade para identificar os fins que são bons. A sabedoria prática é uma virtude 
intelectual que é condição de possibilidade tanto das demais virtudes intelectuais como das virtudes morais, e parece ser o que possibilitará que o agente saiba quando ele deve ser humilde para a heterorregulação e quando deve ter autoconfiança para a autorregulação. ${ }^{17}$

Antes de apontar as características centrais de uma pessoa autônoma frente aos outros agentes, deixem-me estabelecer uma importante distinção aqui, que é entre a autonomia intelectual e a autonomia moral. A autonomia intelectual pode ser consistente com a imagem de um agente que consulta uma dada autoridade competente para saber se fumar faz mal ou para saber que tipo de dieta é mais eficiente para se obter saúde. Mas, não parece ser o caso no campo moral. Aqui, autonomia não seria consistente com a imagem de um agente que consulta uma dada autoridade para saber se deve aprovar o aborto ou condenar a eutanásia, ou mesmo se deve mentir ou ser fiel a um amigo. Como observado corretamente por Benson: “(...) Ser autônomo em moralidade envolve um grau mais elevado de autossuficiência do que ser autônomo intelectualmente" (BENSON, 1983, p. 13). O ponto central da distinção é que no caso moral, como no de querer saber se o aborto e a eutanásia são errados ou se se deve mentir ou ser fiel, a autoridade em questão não poderia ser externa, uma vez que a moralidade exigirá uma autoridade em primeira pessoa, de forma que agir a partir de uma autoridade heterônoma nesses casos parece retirar todo valor que poderia ser atribuído à escolha do agente. Além disso, a diferença é que todos os agentes devem entender dos temas morais, pois para ser um cidadão completo é necessário compreender os direitos e deveres comuns que são assumidos coletivamente. Não seria necessário que todos soubessem sobre medicina ou nutrição, por exemplo, pois nesse campo e outros similares, uma autoridade externa, em terceira pessoa, não parece comprometer o valor do indivíduo. A heteronomia na moral, por outro lado, sendo absoluta, anularia toda possibilidade de censura e responsabilização apropriada. ${ }^{18}$

Após esta importante distinção, encerro a presente seção procurando apontar as principais características da relação de uma pessoa autônoma com os outros, tomando os outros como uma (i) crítica, um (ii) modelo, uma (iii) aprovação e como uma (iv) autoridade. Vejamos. Em relação a (i), a pessoa autônoma tem uma presença de espírito para julgar apropriadamente a crítica, aceitando-a ou recusando-a. Em ambos os casos, o agente não pode ter a disposição ou de aceitar toda crítica, o que implicaria em uma baixa autoestima do agente, ou de recusar toda opinião contrária à sua, o que poderia significar arrogância. Em relação a (ii), a pessoa autônoma tem uma compreensão adequada de quem são os bons modelos, tais como professores, pais ou colegas, tendo uma sabedoria prática ativa sobre o desenvolvimento humano e o seu próprio desenvolvimento. Implica uma autoconsciência suficiente para perceber se alguém está tomando um caminho errado. No que diz respeito a (iii), a pessoa autônoma possui uma orientação disposicional para avaliar os parâmetros da aprovação e penalidades em todas as suas formas. Implica em uma independência da dominação por sanções, não sendo essa independência absoluta, de forma que a autonomia será uma habilidade de manter o valor da sanção em uma categoria 
diferente da do valor dos bens epistêmicos, tais como a verdade e o próprio conhecimento. Por fim, no que toca a (iv), a pessoa autônoma tem uma disposição para levar em consideração apropriadamente a influência legítima de uma dada autoridade obtida ou pela expertise, pelo cargo ocupado ou mesmo pela relação existente com a pessoa, por exemplo, entendendo inteligentemente o estatuto desta autoridade e compreendendo os seus limites (ROBERTS \& WOOD, 2007, p. 272).

Um interessante exemplo de uma pessoa que manteve uma relação autônoma com os outros é Sophie Scholl. Ela foi membro da organização "Rosa Branca", que era um movimento de resistência às políticas nazistas no período da Segunda Guerra Mundial. A organização distribuía panfletos, sobretudo na Universidade de Munique, contra os crimes de guerra cometidos pelos nazistas, defendendo a democracia e a justiça social. Em 1943, foi condenada por traição e executada na guilhotina. É conhecida como uma das poucas pessoas que se opuseram ativamente ao Terceiro Reich no período referido. Sua autonomia pode ser atestada por não ter aceitado as críticas feitas por algumas pessoas, dizendo que ela não deveria atuar ativamente contra o nazismo, pois isso seria perigoso. Também, não tomou certas autoridades acadêmicas como modelos, pois identificou acertadamente que certos professores e mesmo o Reitor estavam tomando o caminho errado de não denunciar os crimes dos nazistas. Não teve medo das sanções possíveis, inclusive considerando que a penalidade nesse caso de desobediência seria a morte. Por fim, não reconheceu como legítima a autoridade política e religiosa da época que defendia práticas eugenistas, não respeitando os direitos humanos. ${ }^{19}$

Uma questão interessante que surge a partir do exemplo heroico de Sophie Scholl é a de saber se todos os demais alemães que não lutaram contra o nazismo agiram a partir de uma ignorância de que "o nazismo é errado" e se essa ignorância poderia ser desculpada ou se ela poderia ser apropriadamente censurada. Imaginando que muitos agentes que apoiaram o regime nazista agiram assim por ignorar a verdade dos direitos iguais de todos os indivíduos, sejam judeus, negros ou homossexuais, agindo erradamente por acreditar de forma malsucedida em uma dada crença $p$, como a que diz que "as práticas eugenistas são corretas", a pergunta é se esse tipo de ignorância seria desculpável ou não. Defendo que a censura terá relação com o estado epistêmico do agente, de forma que se ele não estiver epistemicamente justificado, significando não levar em conta as evidências e os argumentos disponíveis, bem como não refletir detidamente sobre um assunto, ele poderá ser responsabilizado. Adicionalmente à justificação epistêmica, a censura se relacionará com a expressão de certas virtudes, como autonomia e justiça, de maneira que se o agente estiver epistemicamente justificado e agindo autonomamente e justamente, por exemplo, sua ignorância poderá ser apropriadamente desculpada. Mas, veremos isso na última seção. Antes, reflito sobre o papel da virtude da justiça para o problema da ignorância moral. 
A justiça é reconhecida como uma das mais importantes virtudes morais, com a especificidade de ser uma virtude pública. Como toda virtude, é um traço de caráter que é constitutivo da eudaimonia ou florescimento, quer dizer, de uma vida bem-sucedida. Sendo uma virtude moral, ela pode ser tomada como um traço de caráter múltiplo, conectando as diversas emoções dos agentes, suas escolhas, valores, desejos, percepções, atitudes, interesses, expectativas e, também, sua sensibilidade. Como dito por McDowell, a virtude requer uma sensibilidade confiável e implica em uma conduta correta. Por exemplo, a gentileza implica em uma atenção apropriada aos sentimentos das outras pessoas, requerendo uma sensibilidade aos fatos sobre os sentimentos dos outros como razões para agir de certa forma e uma sensibilidade aos fatos sobre a correção como razões para agir de certa maneira. Com isso em mente, podemos compreender a justiça como um traço de caráter, isto é, como uma propensão de agir de uma certa forma, a saber, agir de forma justa, por certas razões, isto é, pela busca da justiça. ${ }^{20}$

Como já identificado pela tradição, a virtude da justiça tem uma relação intrínseca com o outro, ela é um traço de caráter, estabelecido pelo hábito, para dar às pessoas aquilo que lhes é devido, seja em termos de bens a serem distribuídos, seja na forma de uma punição por um ato errado/ilegal. Aristóteles, por exemplo, adota a definição da justiça como a disposição da alma para fazer o que é justo, agir justamente e desejar o que é justo. Para o estagirita, a justiça seria uma perfeita correção de conduta e comportamento. Importante frisar que uma pessoa justa não poderia ser ambiciosa, isto é, não poderia querer mais do que aquilo a que tem direito. A justiça, assim, é frequentemente considerada a virtude moral mais destacada, pois é a virtude perfeita em relação ao próximo. Ela é uma virtude que se efetiva nas relações que um indivíduo mantém com a comunidade (ARISTOTLE, 1999, V, 1, 1128 b 41-1129 a $32)^{21}$

Nesse sentido, a justiça é a virtude moral perfeita em relação ao outro. Isso parece revelar claramente o caráter público ou social desta virtude e parece englobar todas as outras virtudes morais, tais como a generosidade, a benevolência, a clemência, a equidade, entre outras. Por exemplo, a virtude da equidade (epieikeia) é a que interpreta a lei, flexibilizando sua rigidez, determinando o que é justo em cada situação particular. É por esse motivo que o equitativo é justo e é melhor que a justiça legal, embora não seja melhor que a justiça no seu âmbito irrestrito. O equitativo, assim, é uma correção da lei onde esta comete uma omissão devido à sua generalidade, pois a lei não considera todas as situações, de tal sorte que às vezes é preciso criar um decreto. Quando uma determinada situação é indefinida, a regra decorrente também tem de ser indefinida, como acontece, por exemplo, com "a régua de chumbo usada pelos construtores em Lesbos", que se adapta à forma da pedra por não ser rígida, de forma semelhante ao decreto que se adapta aos fatos (ARISTOTLE, 1999, V, 1, 1137 b 56-57).

A justiça, assim como vista pela tradição, é tanto uma qualidade moral do indivíduo como é uma virtude da cidadania, uma vez que ela é a virtude central e unificadora da existência individual e política, 
possibilitando tanto a felicidade pessoal como a coletiva. É a capacidade do agente para reconhecer os contornos relevantes do caso para dar o que é devido aos outros a partir de uma disposição de alcançar a justiça. Mas, também, ela é uma virtude pública que parece assegurar a estabilidade social de forma correta. Esse último significado foi ressaltado pelos autores na modernidade. Por exemplo, para Adam Smith, a justiça é uma virtude negativa e sua observância não está ligada à liberdade da vontade do agente, podendo ser exigida pela força, uma vez que a violação das regras de justiça geraria ressentimento nos membros da comunidade, sendo o que fundamentaria toda punição. A justiça, assim, concerniria às ações de tendências danosas que são objetos apropriados do ressentimento, especificamente do ressentimento empático do espectador imparcial. Ela é uma virtude negativa, pois implicará numa disposição para não fazer mal aos outros, isto é, não causar dano, respeitando os direitos à vida, liberdade e propriedade dos agentes. Também, é uma virtude social que tem uma especificidade: ela obriga absolutamente a todos, diferentemente das virtudes sociais de generosidade, caridade e amizade, por exemplo, que podem ser livremente escolhidas, de forma que apenas a injustiça pode ser punida. Vejase que essa concepção de justiça destaca o critério de imparcialidade, pois a medida de correção será dada pelo espectador imparcial, de forma que nos tornamos justos aprendendo a julgarmo-nos a partir dos olhos dos outros, o que traz por consequência o reconhecimento da igualdade dos agentes. ${ }^{22}$

De forma similar à modernidade, o enfoque contemporâneo revela uma preocupação maior com a justiça pública do que com a justiça pessoal, refletindo mais especificamente sobre as condições de uma sociedade justa. Jonh Rawls, por exemplo, toma a justiça como a virtude primeira das instituições políticas, sociais e econômicas, tais como a Constituição, a família e a propriedade. A ideia básica é que cada pessoa possui uma inviolabilidade moral fundada na justiça que não pode ser desrespeitada nem mesmo pelo objetivo de um maior bem-estar social, o que garante a liberdade e a igualdade dos cidadãos frente a arbitrariedade natural e social. Independentemente do que se pensa que é a justiça, todos podem concordar que as instituições são justas quando nenhuma distinção arbitrária é feita entre as pessoas e quando as regras determinam o equilíbrio entre as reivindicações conflitantes, o que significa dizer que a justiça está sendo interpretada como equidade (fairness) (RAWLS, 1999, pp. 3-5). Embora o foco dessa teoria recaia sob o aspecto social da justiça, pode-se perceber uma importante preocupação com a justiça como uma virtude na compreensão do senso de justiça. As pessoas são caracterizadas por terem senso de justiça, isto é, uma capacidade moral e uma concepção de bem, isto é, uma capacidade racional, o que implica em uma capacidade de perseguir um certo plano de vida. O senso de justiça, por sua vez, é a capacidade de saber o certo e errado, o justo e injusto de uma forma natural, intuitiva. Por exemplo, intuitivamente, sabemos que é errado punir um inocente ou que é errado obter a maximização da felicidade pelo sofrimento de um agente inocente. ${ }^{23}$ 
Na seção 9 de A Theory of Justice, Rawls compara o senso de justiça como o senso de gramaticalidade que todos temos em relação as sentenças de nossa língua materna, fazendo referência a teoria da gramática gerativa de Chomsky, de forma que todo o agente teria uma gramática moral, isto é, uma competência para saber o certo e errado, o justo e injusto em situações cotidianas, mas sua performance estaria relacionada a muitas variáveis, tais como se as instituições públicas que formam o agente são justas ou mesmo se os agentes possuem uma boa disposição. Mas, de todo modo, o agente deve possuir um senso de justiça num grau mínimo que lhe permita conviver com os outros, isto é, que lhe permita ser um cidadão, assumindo certos deveres e reivindicando certos direitos. Dessa forma, ele deverá ter um caráter justo, pelo menos em nível mínimo para evitar a ganância, a inveja, a crueldade, a frieza etc. Isso parece nos conduzir a uma afirmação do critério de reciprocidade que pode já ser identificado nos juízos morais ponderados, juízos que se tem grande confiança, como os juízos que defendem que a intolerância religiosa e a discriminação racial são injustas, e são tomados como ponto de partida para a construção dos princípios de justiça que serão escolhidos em uma situação de simetria, isto é, em uma situação de igualdade (RAWLS, 1999, p. 17-19; 40-46).

A despeito da dificuldade em se determinar o que seria a virtude da justiça, penso que, de posse dessas reflexões já canônicas sobre o tema, podemos identificar quais seriam os critérios normativos relevantes que deveríamos reconhecer em um agente justo, a saber, equidade, imparcialidade e reciprocidade. E isso porque a pessoa justa possui o traço de caráter da justiça, que é uma certa combinação da relevância da vida interna e da razão prática. Essa virtude permite a pessoa justa fixar ou determinar que ações particulares são justas, tanto no sentido distributivo como retributivo, e isso também explica porque uma pessoa justa agiria justamente, a saber, em razão do desejo pela justiça, que é o mesmo que saber que a justiça deve ser feita e a injustiça evitada. Mas, vejamos isso detalhadamente.

Como já tematizado, uma pessoa justa é identificada como tendo a virtude da equidade, que é a capacidade do agente para reconhecer os contornos relevantes do caso para dar o que é devido aos outros a partir de uma disposição de fazer justiça. Pode ser a caso do agente, inclusive, abrir mão daquilo a que teria direito em razão desta disposição em fazer justiça. Também, a decisão equitativa tende a determinar o que é o justo em cada situação particular, corrigindo a generalidade da lei. Por exemplo, a justiça, em certos casos, parece exigir que se descumpra uma certa lei positiva, embora moralmente sejamos obrigados a fazer o que determina a lei, considerando leis injustas, é claro, como as do nazismo ou leis segregacionistas dos Estados Unidos na década de 1950. Aqui um indivíduo justo teria que apoiar certos atos de desobediência em razão de seu desejo de justiça. Talvez os atos de desobediência civil de Martin Luther King e Mahatma Gandhi sejam bons exemplos para melhor compreendermos o comportamento de alguém que é possuidor da virtude da justiça. A imparcialidade, por sua vez, é tomada com a disposição para não causar danos aos outros, o que nos remete a um reconhecimento sobre os direitos à 
vida, liberdade e propriedade, por exemplo, e a consequente obrigação pública decorrente desse reconhecimento. Aqui a medida da justiça é dada pelo olhar dos outros, isto é, ela é social, como na figura de um espectador imparcial. Imaginemos um juiz que julga um caso de corrupção, não observando quem praticou o crime, apenas considerando os fatos relevantes de autoria, materialidade etc. e seguindo o que diz a lei. Por fim, a reciprocidade seria a disposição para não fazer nenhuma distinção arbitrária entre as pessoas, considerando igualmente suas reivindicações conflitantes, sendo uma capacidade intuitiva para saber o que é certo e errado. Por exemplo, um agente justo não poderia tomar como correto punir alguém inocente ou punir em demasia algum agente culpado por razões preventivistas. E isso pela disposição em considerar a todos em uma situação de simetria, tendo os mesmos direitos e deveres, o que parece revelar uma base natural de atitudes de confiança mútua e afeição. ${ }^{24}$

É claro que o agente será mais ou menos justo dependendo de um certo arranjo social. Por exemplo, as instituições sociais, políticas e econômicas, que são base de uma sociedade democrática, podem ser justas ou injustas. Uma sociedade que possui instituições corruptas pode influenciar negativamente na formação do caráter de seus cidadãos. De forma similar, o caráter dos agentes parece estar intrinsecamente relacionado com o tipo de valores morais com que ele se depara na convivência familiar. Considerem um interessante exemplo dado por Susan Wolf sobre as circunstâncias formativas negativas. JoJo é o filho favorito de um terrível ditador, chamado Jo Primeiro, e foi criado para aceitar as regras despóticas de seu pai, ressaltando que seu pai é tomado como seu modelo moral. Assim, JoJo se torna cruel e impiedoso. Aqui teríamos um exemplo de ignorância moral profunda, que seria o mesmo de ter uma visão moral falsa, de forma que a ignorância sobre o erro da crueldade seria decorrente de fatores externos, a saber, os valores familiares. Nessa circunstância de JoJo e em outras similares, provavelmente o agente não poderia ser censurado isoladamente por esta ignorância, uma vez que sua culpa deveria ser repartida com a família ou com a sociedade da qual é fruto. Creio que esses fatores de má sorte moral constitutiva sejam, no mínimo, uma razão atenuante da censura à ignorância. ${ }^{25}$

Deixem-me concluir essa seção fazendo referência a um agente que parece reunir todos esses critérios de equidade, imparcialidade e reciprocidade, sendo tomado como exemplo paradigmático de pessoa justa. Nelson Mandela é considerado por muitos como símbolo de justiça, igualdade e dignidade, tendo sido, inclusive, ganhador do Nobel da Paz. E isso porque teve a disposição de arriscar a própria vida pelo o que acreditou ser justo, a saber, a conquista da liberdade e igualdade para os sul-africanos negros, sendo um símbolo da luta contra o Apartheid. Mesmo tendo ficado vinte e sete anos na prisão, defendeu a reconciliação e não a vingança. Mostrou magnanimidade e tolerância mesmo para os que oprimiram o povo negro por tanto tempo. Depois de presidente da África do Sul, buscou criar uma sociedade multirracial, isto talvez significando o reconhecimento da igualdade e liberdade de todos os 
seres humanos, sejam eles negros ou brancos. Acima de tudo, defendeu que o arrependimento e o perdão seriam mais eficientes do que a pura retribuição para a construção de uma nação. ${ }^{26}$

Pensando nesse exemplo de Mandela no contexto da África do Sul contemporânea, seria interessante perguntar se os sul-africanos que apoiaram o Apartheid poderiam ser apropriadamente censurados por sua ignorância em relação à crença da "discriminação racial ser errada", acreditando de forma malsucedida (não-apta) na superioridade dos brancos, ou se eles deveriam ser desculpados dessa ignorância. Como já antecipado, a estratégia será refletir se os agentes em questão estão justificados epistemicamente ou não e se estão expressando as virtudes de autonomia e justiça. Defenderei que se o agente estiver epistemicamente justificado e agindo virtuosamente, sendo autônomo e justo, sua ignorância poderá ser desculpada. Em contraposição, estando o agente epistemicamente justificado, mas sendo vicioso, isto é, não expressando autonomia nem justiça, ele poderá ser um alvo apropriado de responsabilidade.

\section{V}

Uma forma usual para tentar desculpar a ignorância de alguém a respeito de um certo fato ou norma moral, que é base de um ato errado, é apelar para o argumento da justificação epistêmica. $\mathrm{O}$ argumento defende que um agente não poderia ser apropriadamente censurado por sua ignorância, quando age erradamente, em razão dele estar epistemicamente justificado para acreditar em uma dada crença falsa $p$. Por exemplo, ele leva em consideração as evidências testemunhais e factuais disponíveis, pensa seriamente sobre a questão, não ignora os argumentos favoráveis e contrários envolvidos. Retomando nosso exemplo do nazismo e Apartheid, imaginemos um agente que ignora que a "eugenia é errada" ou que a "discriminação racial é injusta”, pensando que é correto moralmente tanto o extermínio de pessoas, como judeus, negros, homossexuais e doentes mentais, quanto a discriminação da população negra, e que alegue que ele está epistemicamente justificado em acreditar falsamente em $p$, sendo isso uma razão suficiente para ele ser desculpado do ato. Imaginemos que sua alegação tenha por base ter considerado a autoridade do testemunho de um cientista, político ou mesmo de um líder religioso sobre as diferenças entre as raças, ter levado em conta as evidências da biologia e medicina sobre a superioridade da raça branca, bem como não ter ignorado os argumentos contrários. Por fim, sua ignorância sobre a verdade dos direitos humanos não poderia ser censurada, uma vez que o agente teria se esforçado para saber corretamente sobre a questão. Concordando com Harman, em casos assim, penso que é fácil identificar um tipo de argumento falacioso para tentar justificar a crença falsa assegurada pelo agente, até porque ele não estaria apenas confiando no testemunho de uma certa autoridade e confiando em certas evidências, uma vez que existiam testemunhos de outras autoridades, bem como outras evidências factuais, o que parece implicar em uma escolha. Nesses casos é difícil saber o que constitui uma evidência 
para uma crença moral e em que circunstâncias a evidência da pessoa é tal que a resposta correta à evidência, que seria a resposta epistemicamente responsável, envolve acreditar ou não na verdade moral sobre certa questão. ${ }^{27}$

Em situações como essas, parece que o agente falhou em reconhecer a dimensão moral da questão, que seria a dos direitos iguais das pessoas e o correspondente dever de não causar dano aos outros. Penso que seria diferente no caso da escravidão no século XVIII ou, melhor, XVII. Nesse período, a maior parte das evidências factuais, argumentos acadêmicos e testemunhos até mesmo religiosos eram todos ou quase todos favoráveis à escravidão, sem uma compreensão adequada do significado moral dessa instituição. Em casos assim, parece que os agentes que escravizaram a partir de sua ignorância de que "a escravidão é errada", sendo ignorantes de sua ignorância, tiveram a má sorte circunstancial por terem nascido em um período histórico que não problematizou moralmente a instituição em tela, sendo provavelmente uma razão suficiente para a desculpa. Seria distinto se considerarmos a escravidão na segunda metade do século XIX. Nesse período, já havia o movimento abolicionista, obras literárias que mostravam a injustiça da escravidão, testemunhos religiosos em favor da liberdade dos escravos e mesmo argumentos econômicos favoráveis ao trabalho livre. Nesse contexto alternativo, penso, a ignorância sobre o erro da escravidão poderia ser censurada apropriadamente e isso em razão da falha do agente em perceber a relevância moral da questão ou mesmo o significado imoral de seu comportamento. Como defendido corretamente por Sartorio, a condição de censurabilidade estaria no reconhecimento de que ele estaria agindo a partir de razões reprováveis moralmente, estando ciente que as razões que o motivam não são aceitáveis sobre parâmetros morais gerais. ${ }^{28}$

Mas, veja que não é tão simples assim determinar até que ponto o agente tem ou não tem ciência do significado moral de certos atos, o que representa, em certa medida, uma dificuldade ao argumento da condição epistêmica, pois é difícil imaginar uma situação em que o agente estaria epistemicamente justificado de forma absoluta, considerando seriamente todas as evidências, argumentos, pensando autonomamente sobre a questão, até porque se constata que quanto mais um agente ignora um certo assunto, mais ele pensa que o domina. Isso é conhecido como o efeito Dunning-Kruger. Os psicólogos David Dunning e Justin Kruger mostraram que tendemos a superestimar nossas habilidades cognitivas, revelando um fenômeno pelo qual os agentes que possuem pouco conhecimento sobre um tema acreditam saber mais que os outros que seriam os especialistas, ocasionando decisões equivocadas. Esse fenômeno é classificado como um viés cognitivo (cognitive bias), em que as pessoas supervalorizam suas aptidões sociais e cognitivas, estando relacionado com o viés cognitivo da superioridade ilusória. ${ }^{29}$ Essa disfunção cognitiva talvez explique, ao menos parcialmente, porque seria inviável imaginar uma situação de justificação epistêmica em que a ignorância de um agente pudesse ser absolutamente isenta de culpa. Retomemos o exemplo da caça as baleias. Alguém poderia alegar que a ignorância dos agentes sobre a 
aptidão da crença sobre o valor das espécies ameaçadas ou a ignorância sobre o valor da biodiversidade teria sido decorrente de uma justificação epistêmica, de forma que o agente considerou as evidências disponíveis, ponderou os argumentos contra a caça à animais em extinção e, que, sobretudo, não tomou o caso sobre o ponto de vista moral, mas apenas como uma questão cultural. Nessa circunstância, não penso que esse tipo de ignorância seria desculpável, pois há argumentos morais disponíveis de um ponto de vista planetário que deveriam obrigar estes agentes a modificarem suas crenças. Esse tipo de ignorância parece mais ligada às ideias preconcebidas dos agentes, às suas experiências e intuições particulares. Poderia ser tomada como um viés cognitivo de conservadorismo, de forma que o agente não modificaria sua crença da correção em caçar baleias, mesmo quando se depara com novas evidências sobre a importância em se preservar espécies em extinção, por exemplo. Em casos assim, o agente não poderia alegar ser ignorante de sua própria ignorância. ${ }^{30}$

Mesmo considerando apropriada a censura à ignorância sobre o erro em matar baleias, podendo, inclusive, admitir um princípio tal como o defendido por Guerrero $(2007)^{31}$, que exigiria cuidado face um tipo particular de incerteza moral, isto é, que exigiria uma reflexão profunda sobre os contornos morais do caso, de forma que quem violasse esse princípio agiria imprudentemente e seria moralmente culpado do ato, penso que devemos abandonar uma concepção individualista de responsabilidade moral e conhecimento, bem como uma concepção irrealista de agência moral, e passar a considerar o problema da ignorância a partir de uma concepção coletiva de responsabilidade moral e conhecimento, o que parece ser condizente com uma imagem mais factível da agência humana. É por isso que defendo que o agente poderá ser desculpado de um ato errado cometido por ignorância quando ele estiver justificado epistemicamente e expressar certas virtudes na ação, tais como autonomia e justiça, que devem estar conectadas com outras virtudes, tais como integridade, humildade, prudência etc. ${ }^{32}$

A ideia central é que se o agente agir virtuosamente, por exemplo, sendo autônomo e justo, sendo que a virtude já é uma mediedade em relação aos extremos de excesso e deficiência e que precisa da deliberação particular do agente, o que implica uma consideração adequada das razões envolvidas no caso, e estando justificado epistemicamente de forma moderada, a censura à ignorância do agente não seria apropriada. Entretanto, a ignorância que for decorrente de um caráter vicioso poderá ser censurada. Isso quer dizer que se ele agiu ignorantemente e estava moderadamente justificado epistemicamente, mas não agiu autônoma e justamente, por exemplo, então, ele seria um alvo apropriado de censura. Mais claramente, se ele não demonstrar possuir as emoções corretas, não manifestando remorso e arrependimento pelo ato errado do qual é responsável, a censura seria imperativa. Nessa proposta, só podemos censurar alguém por ter uma crença malsucedida ou por não ter reconhecido a relevância moral do caso se a ação foi viciosa. Agindo virtuosamente, ao menos em um nível mínimo que permita ao 
agente ser tomado como cidadão, a ignorância em tela poderá ser desculpada. Aponto, agora, os detalhes da proposta.

Em primeiro lugar, é importante tornar claro o que estou considerando como uma ação autônoma e justa em um nível que permita aos agentes serem tomados como cidadãos. Como vimos em seções anteriores, uma ação autônoma seria um meio termo entre a autorregulação absoluta e a heterorregulação total e, assim, seria uma disposição pessoal para decidir um certo curso de ação usando suas próprias razões, mas levando em conta as razões sociais, é claro. Por outro lado, uma ação justa é uma disposição para não ser ganancioso, dando aquilo a que cada um tem direito, decidir de forma imparcial, não levando em conta os motivos particulares e respeitar a reciprocidade, isto é, a igualdade de todos, além de ser uma capacidade para compreender a relevância moral da situação em questão, corrigindo a generalidade da lei. Os exemplos de pessoas autônoma e justa foram Sophie Scholl e Nelson Mandela, respectivamente. Esses são casos de agentes virtuosos em um nível máximo de heroísmo moral e não seria exequível exigir dos membros de uma comunidade um comportamento semelhante. Assim, penso ser suficiente para os nossos propósitos que o agente seja autônomo e justo de uma forma mais modesta, a saber, da forma com que os cidadãos são exigidos a se comportarem em uma democracia. Por exemplo, somos ensinados na escola e na família e desenvolvermos o pensamento crítico, somos incentivados a resolver problemas e pensar de forma livre e seríamos censurados se todas as nossas decisões fossem pautadas por autoridades externas, tais como escolher uma profissão, o(a) esposo(a), ou um candidato numa eleição, isso sem falar em decisões morais. Também, há uma exigência social para sermos justos no sentido de sermos civilizados no trânsito, razoáveis na convivência com os demais, além de obrigados a não descumprirmos as leis. Nessa dimensão cidadã, tanto a imprudência como a negligência e até mesmo a imperícia seriam passíveis de censura e punição, bem como uma ação danosa com base em uma autoridade heterônoma.

Em segundo lugar, é importante esclarecer o que seria uma justificação epistêmica moderada. Por exemplo, alguém estaria epistemicamente justificado moderadamente se cumprisse as exigências que são feitas aos cidadãos, a saber, de conhecer as leis, não ser imprudente e negligente, ser civilizado, razoável e tolerante, por exemplo. Isso seria diferente de uma justificação epistêmica absoluta. Nesse nível moderado, a justificação apenas exigiria que se considerassem as evidências factuais e testemunhais relevantes, os argumentos disponíveis e se pensasse seriamente no caso ao ponto de não poder ser legalmente punido na ocorrência de um fato danoso. Imaginem o caso de um empresário que lança poluentes em um rio e quando censurado sobre o erro da ação alega ignorar que "não se deve poluir o meio-ambiente", mas que ele estaria justificado epistemicamente em razão de ter levado em conta as evidências testemunhais de políticos e técnicos que negam que haja um problema ambiental planetário, bem como as afirmações de empresários e economistas que dizem que o lucro é tudo o que importa, além de ter pensado seriamente no caso. Considerando que haja leis ambientais no país, essa alegação de 
justificação epistêmica da ignorância não seria uma razão suficiente para a desculpa. Ao contrário, o agente seria facilmente punido por crime ambiental.

Com isso em mente, pode-se considerar que um agente que ignorasse que "a escravidão é errada" no século XVII ou XVIII, digamos um proprietário de escravos, sendo autônomo e justo de forma cidadã e estando justificado epistemicamente de forma moderada, sua ignorância, penso, poderia ser desculpada. Seria diferente no caso do nazismo e Apartheid, bem como no caso da caça às baleias. Nestes cenários, o agente poderia estar epistemicamente justificado moderadamente em sua ignorância do erro da eugenia, discriminação racial e da extinção de uma espécie, considerando a inexistência da proibição legal dos atos em tela, mas isto não seria condizente com as virtudes da justiça e autonomia. Alguém justo teria que reconhecer a igualdade das pessoas, ou mesmo o valor da biodiversidade, bem como teria que desobedecer à certas leis injustas. E alguém autônomo teria que reconhecer a arbitrariedade da discriminação racial e decidir pela mudança de suas crenças. Ser virtuoso parece implicar em uma aspiração para ser melhor, o que significa, em muitos casos, ir além do âmbito legal e rotineiro.

Mas, é claro que alguém poderia objetar, legitimamente, que também no caso da escravidão no século XVII e XVIII um agente justo e autônomo de forma cidadã teria que reconhecer a igualdade das pessoas, bem como teria a obrigação de reconhecer a arbitrariedade da discriminação racial que justificava a instituição da escravidão. Mesmo admitindo a objeção como adequada, é importante ter em mente os aspectos naturais e sociais da ignorância moral. Como vimos, em muitas circunstâncias, julgamos a partir de um viés cognitivo de superioridade ilusória e de conservadorismo, o que nos leva a ignorar a nossa ignorância sobre um certo tema e a não modificar as nossas crenças mesmo quando somos defrontados com evidências contundentes. Acrescido a isso, é importante ter em mente que a correção às distorções no nosso raciocínio moral, o que implicou em maior inclusividade e eliminação das discriminações arbitrárias no juízo ético, ocorreu ao longo da história da humanidade, não sendo uma conquista puramente individual do agente moral.

Com essa ponderação, deixem-me apontar para uma distinção relevante que pode ser útil em nossa discussão. Imaginemos um proprietário de escravos no século XVII ou XVIII que é cruel com os cativos. Além de ignorar que a "escravidão é injusta", ele ignora que a "crueldade é errada". Nesse caso, penso que sua ignorância do erro da crueldade revelaria um caráter vicioso ou uma má vontade, de forma que o agente poderia reconhecer que está agindo a partir de razões morais reprováveis, sendo uma razão suficiente para a censura. Apenas ser proprietário de escravos nesse período referido, sem exibir traços de crueldade, não parece implicar necessariamente em um caráter vicioso do agente, não revelando má vontade, e isso porque no período em tela a escravidão era naturalizada, não sendo um objeto particular de preocupação moral, considerando que esta instituição injusta foi uma constante na história da humanidade. Talvez um herói moral poderia reconhecer o erro da discriminação racial, mas 
provavelmente não seria o caso de um simples cidadão justo e autônomo. ${ }^{33}$ Adicionalmente, podemos imaginar um cenário em que a caça às baleias era naturalizada, o que impediria a censura. Por exemplo, ao lermos Moby Dick, descobrimos que em 1850 as pessoas que caçavam baleias e comiam sua carne também ignoravam que "caçar baleias é errado", mas essa ignorância não parece demonstrar um caráter vicioso dos agentes, pois no período as pessoas não compreendiam a relevância moral do ato, sendo que, inclusive, o óleo desses animais era usado para iluminação. Diferentemente de 2019, em que a ignorância do erro em matar baleias parece revelar um certo caráter vicioso, pois o agente pode reconhecer que está agindo a partir de razões moralmente reprováveis, o que implicará tomá-lo como um alvo correto de censura.

Creio que a vantagem em usar o padrão das virtudes para lidar com o complexo fenômeno da ignorância moral é que ele nos oportuniza um melhor entendimento da responsabilidade moral. E isso porque as virtudes são padrões normativos sociais, isto é, instituídos e exigidos por uma dada sociedade e não padrões normativos abstratos que deveriam ser identificados solipsisticamente. Também, porque o padrão moral das virtudes requererá a deliberação particular de um agente que levará em conta as especificidades do caso. E, assim, a censurabilidade não estaria vinculada apenas a uma falha cognitiva e motivacional do agente em cumprir certas regras, mas estaria vinculada à performance moral dos agentes, performance essa relacionada, também, com os arranjos sociais, políticos e econômicos que circunscrevem toda decisão particular. É claro que ainda teríamos muito a esclarecer a respeito do padrão normativo das virtudes. Por exemplo, qual seria a responsabilidade da comunidade em exigir certas virtudes no comportamento e ações de seus membros ou, mesmo, como fazer para habituar os agentes a possuírem essas virtudes selecionadas? Mas, essas e outras questões ultrapassam o escopo desse artigo, que teve por objetivo central apenas investigar se as ações erradas de um agente cometidas por ignorância de certos fatos ou normas poderiam ser apropriadamente censuradas. Nesse sentido, creio que o padrão normativo das virtudes nos oferece um caminho mais eficiente para a investigação desse problema ainda tão pouco estudado. 


\section{Notas}

${ }^{1}$ Professor do Programa de Pós-Graduação em Filosofia da Universidade do Vale do Rio dos Sinos (UNISINOS), São Leopoldo, R. S., Brasil. E-mail: deniscoitinhosilveira@gmail.com

${ }^{2}$ Ver matéria da Revista Veja sobre o tema, publicada em 1 de julho de 2019, com título: “Após 30 anos, Japão volta a caçar baleias para fins comerciais". A matéria destaca que horas depois de saírem para o mar em 1/7/2019, navios retornaram com duas baleias minke, o que foi considerado um sucesso pelos pescadores. Até o final do ano, 227 baleias serão capturadas, informou a Agência Pesqueira do Japão.

${ }^{3}$ Sobre a história da escravidão no Brasil, especialmente sobre os seus números, ver GOMES, 2019, p. 253-275. Também, faço referência de uma história relevante para nossa investigacão. Zulu Araújo, brasileiro e afrodescendente, que recentemente descobrira ser geneticamente Ticar, vai conhecer suas raízes na localidade de Bakim, Camarões, e em uma entrevista com o rei Gah Ibrahim pergunta como os membros da etnia Ticar foram parar no Brasil. Após um dia de silêncio, o rei responde o seguinte: "Naquele tempo - ele explica -, o chefe do povo tinha autoridade sobre a vida de qualquer pessoa, quando alguém cometia algum crime ou era considerado adúltero, podia ser vendido porque havia demonstrado que não era uma pessoa digna. Os homens brancos já estavam aqui. Como os portugueses, por exemplo, que vinham comprar essas pessoas. É por isso que eu peço que haja uma reconciliação entre nós. Pedimos perdão por tudo o que aconteceu, porque o que os nossos ancestrais fizeram, o fizeram por ignorância” (GOMES, 2019, p. 172-173).

${ }^{4}$ Rik Peels, em sua "Introduction" da obra Perspectives on Ignorance from Moral and Social Philosophy, destaca que a ética teve sempre por tradição focar na responsabilidade das ações, omissões e consequências das ações, não refletindo adequadamente na responsabilidade sobre a ignorância de certos fatos ou normas que são anteriores às ações dos agentes, enquanto a epistemologia esteve sempre confinada a analisar o conhecimento e o que seria necessário para o conhecimento, tal como a justificação epistêmica, não tendo uma preocupação especial no que se toma pelo seu oposto, a saber, a ignorância. Ver PEELS, 2017, p. 1-2.

${ }^{5}$ Irei me contrapor à posição de E. Harman, que diz que somos obrigados a acreditar em verdades morais relevantes para nossas ações, o que implica considerar que a ignorância moral é censurável pela falha em identificar essas obrigações morais, mesmo que o agente não seja culpado de gerir mau suas crenças. De forma semelhante, discordarei da posição cética de Rosen, que diz que somente sãos censuráveis os atos de acrasia e não os casos de ignorância moral, casos em que o agente apenas teria uma responsabilidade derivativa e não original, bem como discordarei da posição de Zimmerman, que diz que a ignorância é sempre desculpável em razão do agente apenas ser indiretamente responsável por ela. Ver HARMAN, 2011, p. 459-460, ROSEN, 2004, p. 295-296 e ZIMMERMAN, 1997, p. 415-416.

${ }^{6}$ Um dos exemplos de Gettier mostra que Smith chega a uma crença verdadeira e justificada por sorte e, assim, essa crença não pode ser tomada por conhecimento. Vejamos por que. A proposição "O homem que conseguirá o emprego tem dez moedas em seu bolso" dita por Smith é verdadeira, mas não é conhecimento, uma vez que quem consegue o emprego é ele mesmo e não Jones, como ele acreditava e estava justificado em sua crença em razão de uma evidência testemonial e, por sorte, ele também possuía dez moedas em seu bolso. Ver GETTIER, 1963, p. 122. A epistemologia da virtude parece ter por pressuposto tomar o conhecimento não como uma crença verdadeira justificada, mas como um tipo de performance em que se é bem-sucedido. Por exemplo, Ernest Sosa defende, em A Virtue Epistemology, que o conhecimento deve ser compreendido como algo que é resultado das virtudes intelectuais de um agente, tendo por foco as habilidades e caráter do agente. Para ele, o conhecimento é um tipo de performance bem-sucedida (apta), sendo a performance um tipo de ação que visa a verdade. Ver SOSA, 2007, p. 22-23.

${ }^{7}$ Rik Peels define a ignorância a partir das atitudes doxásticas, afirmando que ela é uma atitude mental em relação a uma crença verdadeira, podendo ser vista como (i) ter uma crença falsa, (ii) suspender o juízo sobre uma proposição verdadeira, (iii) não ter ideia sobre a proposição verdadeira ou (iv) estar incerto. Ver PEELS, 2010, p. 62-64.

${ }^{8}$ O termo "condição epistêmica" da responsabilidade é usado por Fischer e Ravizza, que corresponde a ausência de ignorância. Esta condição captura a intuição básica de que um agente é responsável apenas se ele sabe os fatos específicos que envolvem a ação e sua ação se dá a partir de crenças e intuições apropriadas. A condição metafísica da responsabilidade, isto é, a condição de poder escolher entre possibilidades alternativas, é chamada por eles de "condição de controle". Ver FISCHER \& RAVIZZA, 1998, p. 13.

${ }^{9}$ Peels também faz essa distinção entre fatos e normas. Há a ignorância de certos fatos, como o de não saber do dano causado à natureza e aos animais na produção de certos alimentos. Essa ignorância é passível de censura, uma vez que poderíamos checar facilmente esses produtos alimentícios antes de comprá-los. Mas, também há a ignorância de certas normas, como no 
caso da ignorância dos terroristas do Estado Islâmico a respeito dos direitos individuais, sendo essa ignorância também passível de censura em razão dos agentes poderem reconhecer a validade universal desses direitos, sobretudo, se observarmos a censura do mundo ocidental. Ver PEELS, 2017, p. 1-2.

${ }^{10}$ Vários filósofos compatibilistas defendem esse ponto, uma vez que a censura não estaria baseada na possibilidade de se agir diferentemente, mas pelo ato manifestar alguma qualidade importante do agente, tal como suas motivações e valores assumidos. Mason, por exemplo, defende que nem todos os agentes moralmente ignorantes e passíveis de censura cometeram uma falta epistêmica, sendo a má vontade crucial para se entender esse fenômeno, tomando a própria ignorância moral como uma forma de má vontade. Ver MASON, 2015, p. 3037-3039. Já Arpaly defende que um agente manifesta má vontade apenas quando ele ignora alguma evidência. Ver ARPALY, 2003, p. 104.

${ }^{11}$ Parece haver uma pluralidade de significados de censura. Uma forma óbvia envolve uma avaliação negativa do caráter do agente vicioso, envolvendo um juízo aretaico negativo do agente. Também, pode ser vista como a expressão de uma emoção moral, tal como ressentimento ou indignação, vista como uma atitude reativa. Uma outra forma de interpretá-la é percebê-la como uma mudança de expectivas em relação ao agente que não cumpre seus deveres em razão de uma identificação de uma ação errada cometida. Por fim, também pode-se identificar a censura como um tipo de comunicação ao agente do seu erro cometido, sendo um tipo de exigência por desculpas. Sobre a natureza da censura e um melhor entendimento das várias teses sobre o assunto, ver COATES; TOGNAZZINI, 2013, p. 3-26. Sobre os aspectos cognitivo, conativo, emocional e comunicativo da censura ver, respectivamente, WATSON, 2004, p. 265; SCANLON, 2010, p. 123-138; STRAWSON, 2008, p. 4-22 e SMITH, 2013, p. 41-48.

12 Para Martha Nussbaum, o perdão é um processo entre duas pessoas envolvendo a moderação da raiva e a interrupção da vingança. E o candidato ao perdão deve: (i) ser um agente responsável, (ii) repudiar o erro cometido, (iii) expressar arrependimento pelo dano causado, (iv) comprometer-se em tornar-se uma pessoa melhor, (v) mostrar que compreende o dano causado pelo ato errado, (vi) oferecer uma narrativa para mostrar que seu erro não expressa a totalidade da pessoa que é. Ver NUSSBAUM, 2016, p. 57. Ver, também, GRISWOLD, 2007, p. 149-150.

${ }^{13}$ Kant, em "An Answer to the Question, What is Enllightenment”, explica que o lema do Esclarecimento é a coragem de saber, Sapere Aude, que é a coragem de usar a própria razão, o que implica usar o seu próprio entendimento sem direção de outrem, não sendo tutelado. Assim, autonomia individual é a capacidade de viver de acordo com as próprias razões e motivos dados pelos agentes. Ver KANT, 1996, p. 17. Do ponto de vista moral, autonomia significa a capacidade de dar-se leis morais a si mesmo, de forma a reconhecer racionalmente que as ações corretas são aquelas que se desejam que sejam universalizadas e que não instrumentalizam ninguém. Assim, a autonomia da vontade é o princípio supremo da moralidade. Ver KANT, 1998, pp. 19-51. Para o conceito de autonomia, ver o verbete de John Christman em The Stanford Encyclopedia of Philosophy, "Autonomy in Moral and Political Philosophy”, 2015.

${ }^{14}$ A teoria da mediedade em Aristóteles diz que a virtude é encontrada como um meio termo justo entre dois extremos que são considerados sempre viciosos, um por excesso e outro por deficiência, sendo a espécie da virtude. Por exemplo, a coragem é uma mediedade entre a temeridade, por um lado, que é o não ter medo de nada, não considerando adequadamente a própria segurança e a covardia, por outro, que é o ter medo de todas as coisas, superestimando a própria segurança. Ver ARISTOTLE, Nicomachean Ethics, 1999, 1107 a1-4.

${ }^{15}$ Importante destacar a dimensão coletiva do pensamento, uma vez que ele é um ato de seguir regras e um ato de seguir regras é eminentemente social e, sendo assim, o próprio pensamento seria um ato eminentemente social. Sobre o conhecimento ser uma atividade coletiva e uma visão naturalística da prática de seguir regras, ver PETTIT, 1993 , p. $175-193$. Sobre a moralidade ser uma construção social em bases naturais, ver PETTIT, 2018, p. 13-56. Witgesntein também defende que a linguagem é um empreendimento intersubjetivo e socialmente mediado, sendo o próprio significado das palavras encontrado no seu uso. Ver WITTGENSTEIN, 2001, § 202-248.

${ }^{16}$ Buchanan e Powell explicam o progresso moral a partir de uma teoria biocultural, em que destacam os aspectos naturalísticos dessa evolução, bem como ressaltam os aspectos culturais desse fenômeno. O ponto central destacado por eles é que o progresso no campo da ética implicaria em reconhecer uma maior inclusividade, de forma a vê-lo como uma expansão do círculo moral, passando a incluir na preocupação ética os outros povos, pessoas de outras etnias, as mulheres, os animais não-humanos e mesmo a natureza, sendo uma correção do raciocínio moral, de forma a exigir coerência e a exclusão de toda arbitrariedade, como seria o caso de se levar em conta o gênero e a etnia de um dado agente na avaliação moral. Ver BUCHANAN \& POWELL, 2018, p. 15; 55-56.

${ }^{17}$ Como afirmado por Roberts e Wood, a autonomia é mais um traço de caráter do que um conhecimento específico de alguma área. É um tipo de sabedoria prática, de forma a ter uma compreensão geral suficiente do que está no centro do seu conhecimento, inclusive reconhecendo os seus limites. Outras virtudes devem estar ligadas à autonomia, a saber, a 
autoconfiança, de forma a ter coragem para decidir e agir de forma independente, e a humildade, de maneira a reconhecer a limitação autorregulativa. Importante ressaltar que autonomia não é uma questão de criatividade, mas de amor ao bem epistêmico da verdade. Ver ROBERTS \& WOOD, 2007, p. 265-266. E sobre a sabedoria prática como um tipo de deliberação para identificar os meios necessários para realizar um fim que é bom, com a caracterização dos elementos da razão prática, ver ROBERTS \& WOOD, 2007, p. 305-312.

${ }^{18}$ Benson chama atenção corretamente que no campo moral não há expertos, isto é, não haveria uma autoridade última que deveria ser ouvida e obedecida por todos, enquanto que no campo científico estamos acostumados a ouvir o especialista para resolver um certo problema. A questão é que no domínio moral todos os agentes deveriam exercitar sua autonomia para saber o que se deve fazer e como se deve viver. Ver BENSON, 1983, p. 12-15.

${ }^{19}$ Para mais detalhes da história de Sophie Scholl e do movimento "Rosa Branca", ver o livro de Frank McDonough, chamado Sophie Scholl: The Real Story of the Woman who Defied Hitler, de 2009.

${ }^{20}$ McDowell define a virtude como uma propensão de agir de certa forma por certas razões, consistindo em uma capacidade perceptual para identificar as circunstâncias relevantes do caso, possuindo um componente apetitivo em uma sensibilidade presumida. Assim, virtude seria uma habilidade de reconhecer as exigências em que a situação impõe um certo tipo de comportamento, exigindo uma sensibilidade complexa. Ver McDOWELL, 1997, p. 141-147.

${ }^{21} \mathrm{Na}$ compreensão aristotélica, que é similar a de Platão, e que é seguida, também, por Tomás de Aquino, a justiça é a forma perfeita da virtude porque ela é a prática efetiva da virtude perfeita. Em suas palavras: "Ela é perfeita, porque as pessoas que possuem o sentimento de justiça podem praticá-la, não somente em relação a si mesmas, como também em relação ao próximo" (ARISTOTLE, 1999, V, 1, 1130 a 7-9).

${ }^{22}$ Adam Smith, em The Theory of Moral Sentiments, diz que a justiça é uma virtude negativa que especificamente nos proíbe de causar dano aos nossos vizinhos. Comenta que a pessoa que se abstém de violar os direitos dos outros, ou do Estado, ou a reputação de seus vizinhos, teria seguramente muito pouco mérito positivo. Entretanto, com essa abstenção, ela preenche todos os requisitos necessários para ser considerada uma pessoa justa, cumprindo sua obrigação pública e, assim, não podendo ser punida. Ver SMITH, 1976, II.ii.I.2.

${ }^{23}$ No artigo "The Sense of Justice", Rawls afirma que o senso de justiça não apenas está conectado com os sentimentos morais de ressentimento, indignação e culpa, mas, também, com as atitudes naturais de confiança mútua e afeição. Ver RAWLS, 1968, p. 281-282.

${ }^{24}$ Sobre a reciprocidade em um sentido naturalístico, pode-se pensar que em espécies cooperativas, tal como a humana, há uma clara aversão à desigualdade, uma vez que a base da cooperação parece ser a reciprocidade. Por exemplo, a caça aos grandes mamíferos no Pleistoceno só foi possível com trabalho cooperativo humano, o que resultou em uma certa compreensão de igualdade entre os cooperantes, bem como um critério para a censura aos não cooperantes. Ver LEBAR, 2018, p. 6-7. Ver, também, BUCHANAN \& POWELL, 2018, p. 26-34; 121-123.

${ }^{25}$ Wolf considera JoJo como alguém cujas ações são controladas pelos seus desejos e tais desejos são os desejos que ele quer ter, significando que suas ações são governadas por certos desejos que expressam o seu eu profundo. O ponto é dizer que JoJo não seria responsável por suas ações em razão de seu eu profundo não ter sido sua escolha, mesmo que suas ações sejam governadas isto. Assim, o critério de sanidade é a condição de responsabilidade moral, que é a capacidade cognitiva e normativa de entender e apreciar o mundo como ele é. Ver WOLF, 2003, p. 379-387.

${ }^{26}$ Martha Nussbaum faz referência à justiça como ligada as virtudes de generosidade e autorrestrição. Dessa forma, a justiça deve estar ligada às emoções adequadas para possibilitar a misericórdia e o perdão, com um foco preferencial no futuro ao invés do passado, o que teria ligação com a raiva e a vingança. A justiça também deve estar ligada a uma capacidade de autorrestrição, o que pode aplacar a força da raiva e do ódio em muitas sociedades. Ver NUSSBAUM, 2016, p. 209. Sobre a vida de Mandela, ver BARNARD, 2014, p.1-26.

${ }^{27}$ A objeção de Harman ao argumento da justificação epistêmica tem por base uma certa desconfiança se o agente de fato levou em consideração as evidências disponíveis para fundamentar sua ação. Ela defende que as pessoas que conhecem os fatos não-morais do que estão fazendo, quando fazem coisas erradas, geralmente possuem evidências suficientes de que suas ações são erradas e isso é censurável. Ver HARMAN, 2011, p. 462.

${ }^{28}$ Carolina Sartorio defende que a condição epistêmica para a responsabilidade moral de um agente não estaria em sua crença em alternativas ou em sua crença que faz algo errado, mas por estar ciente do significado moral de seu comportamento. Faz referência a uma variação do famoso exemplo de Frankfurt, em que Jones estaria consciente do fato do neurocientista ter o 
controle do seu cérebro e, assim, não poder agir diferentemente, digamos para matar Smith. Acontece que a decisão de Jones é a de matar Smith por vingança e ele pode ser censurado pelo ato mesmo considerando que ele não tem uma crença que fez algo errado ou uma crença em alternativas. Jones seria censurado porque decidiu por suas próprias razões se vingar de Smith. Ver SARTORIO, 2017, p. 25.

${ }^{29}$ O efeito Dunning-Kruger revela que os que mais tendem a ter uma ideia melhor sobre si mesmos são exatamente os menos capacitados: quanto menos sabemos sobre um tema, mais tendemos a achar que sabemos o suficiente. O estudo realizado pelos psicólogos mostrou que os mais ignorantes sobre lógica, gramática e humor julgavam saber quase tanto quanto os especialistas nesses temas. Ver KRUEGER \& DUNNING, 1999, p. 1121-1134.

${ }^{30}$ Viés cognitivo (cognitive bias) é um erro sistemático no pensamento, o que resulta em um ato irracional. Por exemplo, o conservadorismo, neste contexto cognitivo, é a tendência do agente a não revisar suas crenças mesmo quando ele se depara com novas e importantes evidências testemunhais ou factuais, ou mesmo com novos argumentos consistentes. Sobre o tema, ver EDWARDS, 1982, p. 359-369.

${ }^{31}$ Guerrero afirma que nossas obrigações epistêmicas crescem quando o contexto se torna moralmente mais sério, defendendo o princípio “Dont't Know, Don't Kill”, de forma que se alguém sabe que ignora se um organizamo vivo tem status moral significativo ou não, é moralmente censurável para ele matar esse organismo, a menos que ele acredite que exista algo moralmente significativo que o obrigue à ação. Ver GUERRERO, 2007, p. 79-83.

${ }^{32} \mathrm{O}$ ponto é que as virtudes epistêmicas e morais estão intrinsecamente conectadas na ação de um agente virtuoso, de forma que elas devem ser compreendidas holisticamente. Isto significa que alguém autônomo também deve manifestar a virtude da humildade, que seria a disposição de não ser o detentor da exclusivo da verdade e nem de inflar seu próprio valor, impedindo a arrogância e a vaidade, além de ter que manifestar a virtude da integridade, que é a disposição para perseguir a verdade. De forma similar, alguém justo também deve manifestar generosidade, benevolência e clemência em certas situações. Sobre a unidade das virtudes, ver ANNAS, 2011, p. 83-99.

${ }^{33}$ Parece que nem mesmo os filósofos identificaram facilmente a injustiça da escravidão. Inclusive, diversos filósofos iluministas sustentaram a ideia de que o negro seria naturalmente inferior ao branco, a saber, David Hume, Immanuel Kant, Voltaire e Hegel, entre outros, o que sustentava a ideia de correção da escravidão. Em 1837, no livro A Filosofia da História, Hegel escreve que a falta de controle distinguiria o caráter dos negros, sendo essa condição um incapacitador do desenvolvimento e da cultura e, por essa razão, a única essencial ligação que existiria e teria permanecido entre os negros e os europeus seria a da escravidão. Ver GOMES, 2019, p. 75-76. Também, John Locke, pensador liberal e humanista, inclusive, foi acionista da Royan African Company, companhia privada britânica responsável pelo tráfico de escravos. Ver GOMES, 2019, p. 238. 


\section{Referências}

ANNAS, J. Intelligent Virtue. Oxford: Oxford University Press, 2011.

ARISTOTLE. Nicomachean Ethics. Trans. Terence Irwin. 2a. Ed. Indianapolis: Hackett, 1999.

ARPALY, N. Umprinciped Virtue: An Inquiry Into Moral Agency. New York: Oxford University Press, 2003.

BARNARD, R. Introduction. In: BARNARD, R. (Ed.). The Cambridge Companion to Nelson Mandela. New York: Cambridge University Press, 2014, p. 1-26.

BENSON, J. Who is the Autonomous Man? Philosophy, v. 58, n. 223, 1983, p. 5-17.

BUCHANAN, A.; POWELL, R. The Evolution of Moral Progress: A Biocultural Theory. New York: Oxford University Press, 2018.

CHRISTMAN, J. Autonomy in Moral and Political Philosophy. The Stanford Encyclopedia of Philosophy, 2015.

COATES, J.; TOGNAZZINI, N. The Contours of Blame. In: COATES, J.; TOGNAZZINI, N. (Eds.). Blame: Its Nature and Norms. New York: Oxford University Press, 2013, p. 3-26.

DA REDAÇÃO. Após 30 Anos, Japão Volta a Caçar Baleias para Fins Comerciais. Revista Veja, $1 / 07 / 2019$.

EDWARDS, W. Conservatism in Human Information Processing. In: KAHNEMAN, D.; SLOVIC, P.; TVERSKY, A. (Eds.). Judgement Under Uncertainty: Heuristics and Biases. New York. Cambridge University Press, 1982, p. 359-369.

FISCHER, J.; RAVIZZA, M. Responsibility and Control: A Theory of Moral Responsibility. New York: Cambridge University Press, 1998.

GETTIER, E. Is Justified True Belief Knowledge? Analysis, v. 23, n. 6, 1963, p. 121-123.

GOMES, L. Escravidão: Do Primeiro Leilão de Cativos em Portugal até a Morte de Zumbi dos Palmares, Volume I. Rio de Janeiro: Globo Livros, 2019.

GRISWOLD, C. Forgiveness: A Philosophical Exploration. Cambridge: Cambridge University Press, 2007.

GUERRERO, A. Don't Know, Don't Kill: Moral Ignorance, Culpability, and Caution. Philosophical Studies, v. 136, 2007, p. 59-97.

HARMAN, E. Does Moral Ignorance Exculpate? Ratio, v. XXIV, 2011, p. 443-468.

KANT, I. An Answer to the Question What is Enlightenment? In: Practical Philosophy. Trans. Mary G. Cambridge: Cambridge University Press, 1996. 
University Press, 1998.

Groundwork of the Metaphysics of Morals. Trans. Mary Gregor. Cambridge: Cambridge

KRUEGER, J.; DUNNING, D. Unskilled and Unaware of It: How Difficulties in Recognizing One's Own Incompetence Lead to Inflated Self-Assessments. Journal of Personality and Social Psychology, v. 77, n. 6,1999 , p. 1121-1134.

LEBAR, M. (Ed.). Justice. The Virtues. New York: Oxford University Press, 2018.

MASON, E. Moral Ignorance and Blameworthiness. Philosophical Studies, v. 172, n. 11, 2015, p. 30373057.

McDONOUGH, F. Sophie Scholl: The Real Story of the Woman who Defied Hitler. Cheltenham: The History Press, 2009.

McDOWELL, J. Virtue and Reason. The Monist, v. 62, 1979, p. 331-350. Rep. In: CRISP, R.; SLOTE, M. (Eds.). Virtue Ethics. New York: Oxford University Press, 1997, p. 141-162.

NUSSBAUM, M. Anger and Forgiveness: Resentment, Generosity, Justice. New York: Oxford University Press, 2016.

PEELS, R. Introduction. In: PEELS, R. (Ed.). Perspectives on Ignorance from Moral and Social Philosophy. New York: Routledge, 2017, p. 1-14. . What is Ignorance? Philosophia, v. 38, 2010, p. 57-67.

PETTIT, P. The Common Mind: An Essay on Psychology, Society, and Politics. New York: Oxford University Press, 1993.

. The Birth of Ethics: Reconstructing the Role and Nature of Morality. New York: Oxford University Press, 2018.

RAWLS, J. A. Theory of Justice. Revised Edition. Cambridge, MAS: Harvard University Press, 1999. . The Sense of Justice. Philosophical Review, v. 72, n. 3, 1963, p. 281-305.

ROBERTS, R. C.; WOOD, W. J. Intellectual Virtues: An Essay in Regulative Epistemology. New York: Oxford University Press, 2007, p. 257-285.

ROSEN, G. Skepticism about Moral Responsibility. Philosophical Perspectives, v. 18, 2004, p. 295313.

SARTORIO, C. Ignorance, Alternative Possibilities, and the Epistemic Conditions for Responsibility. In: PEELS, R. (Ed.). Perspectives on Ignorance from Moral and Social Philosophy. New York: Routledge, 2017, p. 15-29.

SCANLON, T. Moral Dimensions: Permissibility, Meaning, Blame. Cambridge, MAS: Harvard University Press, 2010. 
SMITH, A. The Theory of Moral Sentiments. Edited by RAPHAEL, D. D and MACFIE, A. L. The Glasgow Edition of the Works and Correspondence of Adam Smith. Oxford: Oxford University Press, 1976.

SMITH, Angela. Moral Blame and Moral Protest. In: COATES, J.; TOGNAZZINI, N. (Eds.). Blame: Its Nature and Norms. New York: Oxford University Press, 2013, p. 27-48.

SOSA, E. A. Virtue Epistemology: Apt Belief and Reflective Knowledge. Volume I. Oxford: Clarendon Press, 2007.

STRAWSON, P. Freedom and Resentment and Other Essays. New York: Routledge, 2008.

WATSON, G. Agency and Answerability. Oxford: Clarendon Press, 2004.

WittGensteIn, L. Philosophical Investigations (Philosophische Untersuchungen). Third Ed. Trans. G. E. Anscombe. Oxford: Blackwell Publishing, 2001.

WOLF, S. Sanity and the Metaphysics of Responsibility. In: WATSON, G. (Ed.). Free Will. Second Edition. Oxford: Oxford University Press, 2003, p. 372-387.

ZIMMERMAN, M. Moral Responsibility and Ignorance. Ethics, v. 107, n. 3, 1997, p. 410-426. 